\title{
The Impact of Technology Factors on the Workers' Productivity an Empirical Study on Al Borg Cement Factory in Libya
}

Anwer AM Niri*

University of Singidunum, Belgrade, Serbia

\begin{abstract}
This paper provides information about the worker's productivity of Al Borg Cement Factory in Libya. It clearly outlines the productivity decrease that faces employees inside of workplace from the drop of performance. The article further argues that the deficiency in the perfect usage of technology, computer systems, communication networks (internet) and Lack of interest of the organization to prepare a training schedule. These factors are among other factors which effect on the productivity causing the employees to be less productive at their workplaces. Additionally, this has the negative effect on the economy. In addition, the decrease of individual productivity is evidenced via the outcome of the survey of individuals who shortage of interest of the management to prepare a time training schedule and system of computing to work at Al Borg Cement Factory within the country of Libya. Therefore, the paper recommends measures which should be taken to improve productivity by workers training on technology it can be that inside or outside in this organization, which could lead to improvement in the economic development of Al Borg plant and Libya in general.
\end{abstract}

Keywords: Technology; Training; Computing systemize; Internet; Productivity

\section{Introduction}

Over the past many decades there are dramatic changes within the forms of technologies offered to businesses whether public or private. The speedy development and diffusion of recent data technologies such as computers, communications and networks has altered the production process in several workplaces. In conjunction with these basic changes in the physical capital of firms, it is conjointly wide believed that the introduction of those new technologies has altered the structure of employment [1]. Employers and policymakers have emphasized the importance of talent upgrading of employees and long learning so as to deal with accrued pressures elicited by technological modification and economic process (e.g.; European Commission, 2007). whereas there exists an oversized literature showing that the accumulation of human capital through the overall education system plays a vital role in explaining long financial gain differences between wealthy and poor countries, abundant less work exists on the consequences of training provided by companies, usually requiring specific skills from their employees.

In his seminal work, Becker created a distinction between firmspecific and general training. General training ends up in skills that are equally applicable to alternative corporations whereas skills acquired through firm-specific coaching area unit lost once the skilled worker leaves the... firm that provided coaching. Below excellent competition within the market, employees ought to get hold of prices of general training and recoup these prices by earning higher wages. Once training is particular, firm pay (part of) the training costs. However, Acemoglu and Pischke indicate that in varied cases companies offer and get hold of training which is general in nature. They show however this could be explained by labor market imperfections. Particularly, a necessary condition for companies to get hold of general training is that wages increase less steeply in training than productivity. This can be stated as a compressed wage structure which may be caused by frictions within the market like search prices, informational asymmetries, potency wages and labor markets establishments like unions or the presence of earnings laws. With a compressed wage structure, training will increase the marginal product of labor over wages that creates incentives for the firm to take a position in training. This can be stated as a compressed wage structure which may be caused by frictions within the market like search prices, informational asymmetries, potency wages and labor markets establishments like unions or the presence of earnings laws. With a compressed wage structure, training will increase the marginal product of labor over wages that creates incentives for the firm to take a position in training. Therefore of these, in recent years that computer power itself has enabled researchers to statistically interrogate largescale datasets on firms, organizations and providing some more solutions to these issues [2].

The importance of skill upgrading of workers and lifelong learning in order to cope with increased pressures induced by technological change and globalization (e.g.: European Commission, 2007). However, while there exists a large literature showing that the accumulation of human capital through the general education system plays a crucial role in explaining long run income differences between rich and poor countries. Much less work exists on the effects of training provided by firms, often requiring specific skills from their workers [3]. The paper is structured as follows. In the following section, we briefly review the main trends in the empirical literature devoted to the analysis of the impact of technologies (computing and communications) on productivity, also; the impact of training on productivity. In other section, reports and discusses the results of the statistical analysis. Finally, the last section concludes, highlighting the main implications of our results.

\section{Review of Relevant Literature}

Studies carried out in works by Kristen and Lee [4], they have

*Corresponding author: Anwer AM Niri, University of Singidunum, Belgrade Serbia, Tel: 00381612373818, 00218928059838; E-mail: anweranare@yahoo.com

Received May 15, 2017; Accepted June 12, 2017; Published June 14, 2017

Citation: Niri AAM (2017) The Impact of Technology Factors on the Workers' Productivity an Empirical Study on Al Borg Cement Factory in Libya. Int J Econ Manag Sci 6: 435. doi: 10.4172/2162-6359.1000435

Copyright: (C) 2017 Niri AAM. This is an open-access article distributed under the terms of the Creative Commons Attribution License, which permits unrestricted use, distribution, and reproduction in any medium, provided the original author and source are credited. 
validated the fact that workers on their productivity are affected by the Internet. They reported that the six in ten approximately $61 \%$. American workers who use the internet say email is "very important" for doing their job, and $54 \%$ say the same about the internet. Far fewer workers describe landline phones (35\%) or cell phones and smartphones (24\%) as "very important." Just $4 \%$ say social networking sites like Twitter, Facebook or LinkedIn are "very important" to their work. Moreover, according to Kimmo [5] indicated that to increase productivity, the employer should have up-to-date internal communication guidelines and organize training and other support for employees, particularly when new communication tools are taken into use. More than that, including sharing, archiving relevant information and documents also should be available for co-employees as a common practice. Additionally, to evaluate the degree of workers skills and recording the production at work, it is possible to estimate the impact of the training on productivity at the workplace as indicated by Jozef and Stijn. For a better understanding of the issue, a chain of definitions gives below indicating their will corresponding relationships in Figure 1.

\section{The definition of the organizational concepts is provided below as follows}

Productivity characterizes the efficiency of productive output of workers, which is expressed by the number of products per unit time. Performance is the value of functional abilities of the body characterized by the quantity and quality of work at maximum intensity or activity. The type of performance and frequency of its changes are related to the duration of human Functional State (FS) phases outlined in works by Doroshev [6] and Gavrilov et al. [7]. According to Rohan and Madhumita [8] companies, today are forced to function in a world full of change and under various complications, and it is more important than ever to have the correct employees at the correct job with the right qualification and experience in order to survive the surrounding competition. The successful and prosperous future of an organization is dependent on its skilled, knowledgeable and well-experienced workforce that is why training is a fundamental and effectual instrument in the successful accomplishment of the firm's goals and objectives. Training not only improves them resourcefully, but also gives them a chance to learn their job virtually and perform it more competently hence increasing firm's productivity Training has been an important variable in increasing organizational productivity, according to the Researchers' comments including Colombo and Stanca [9], Sepulveda [10], Konings and Vanormelingen [11].

\section{Research Methodology}

Due to the advantages presented by the of data analysis, these approaches are adopted to analyze the statistical data by the survey method was used for data. Although most of the information related to technology and workers' productivity were collected through interviews and survey, these interviews were carried out based on the questionnaires with statistical data analysis. This survey included 50 from 200 employees whose are work in the Al Borg Cement Factory in Libya while the real return of questionnaires form were 37 from 50 applications were applied on employees in this survey. The attitudinal questions attempted to reveal the viewpoints, opinions, and the perceptions of the interviewees with respect to the different dimensions and variables of the technology, communication, training, and productivity by using the Likert scale has been utilized to measure the study sample. In order to derive a usable questionnaire for this research, many standard questionnaires regarding technology and productivity were investigated.

Furthermore, the reliability of the questionnaire in these studies has been assessed by Cronbach's alpha as percent (0.946), which is an appropriate criterion for evaluating the reliability of the measurement tools. And through a pre-test is done by using the SPSS package and Cronbach test. In Tables 1 and 2 below illustrate that the total reliability of the questionnaire was determined.

\section{Results and Discussion}

This study examined the relationship between technology and workers' productivity in, Al Borg Cement Factory in Libya. The empirical data collected is based on the perceptions and opinions of factory's employees. Data analysis was used to test via a statistical program which is SPSS. Results of this case study in Al Borg Cement Factory in Libya indicated that a positive relationship exists between technology and productivity.

\section{Technology and productivity}

The analysis provided strong supporting for the relevance of the technology on productivity. Moreover, there is a correlative relationship between technological changes and productivity of the individual. The more of administration is interested in keeping up with the modern and advanced technological changes to achieve the more productivity. The findings of this study indicated that the perceived usefulness of technology has a significantly positive influence on employee's productivity. In summary, results of the data analysis for our research are as shown below in Table 3. As a result, In this section, it can be shown the correlation between technology and individuals productivity in the plant in terms of the percent of answer workers is around $90 \%$ which say their company encourage employees and important to make modern technology.

\section{Collecting information}

The plant management based on to retain all data and information about customers by technological services. It has reduced by the employee's survey that the prevalent situation in this company which the most its workers whose are affected by technology and help them in increased product. Therefore, the factory might keep whole documents

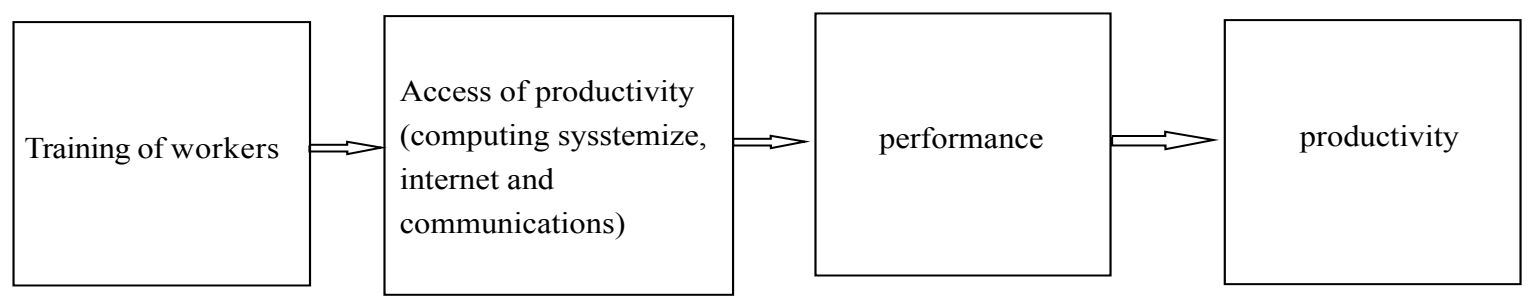

Figure 1: Diagrammatic scheme of the relationship among technology and productivity. 


\begin{tabular}{|c|c|c|c|}
\hline Cases & & N & $\%$ \\
\cline { 2 - 4 } & Valid & 37 & 100 \\
\cline { 2 - 4 } & Excluded & 0 & 0 \\
\cline { 2 - 4 } & Total & 37 & 100 \\
\hline
\end{tabular}

Table 1: Case processing summary.

\begin{tabular}{|c|c|}
\hline Cronbach's Alpha & No. of Items \\
\hline 0.946 & 35 \\
\hline
\end{tabular}

Table 2: Reliability statistics.

\begin{tabular}{|l|c|c|c|c|c|}
\hline Valid & Frequency & Percent & $\begin{array}{c}\text { Valid } \\
\text { percent }\end{array}$ & $\begin{array}{c}\text { Cumulative } \\
\text { percent }\end{array}$ \\
\cline { 2 - 6 } & Disagree & 2 & 5.4 & 5.4 & 5.4 \\
\hline \multirow{2}{*}{ Neutral } & 2 & 5.4 & 5.4 & 10.8 \\
\hline Agree & 21 & 56.8 & 56.8 & 67.6 \\
\hline \multirow{2}{*}{ Strongly Agree } & 12 & 32.4 & 32.4 & 100.0 \\
\hline & Total & 37 & 100.0 & 100.0 & \\
\hline
\end{tabular}

Table 3: Management recognizes the importance of technology in the plant.

\begin{tabular}{|c|c|c|c|c|c|} 
Valid & Frequency & Percent & $\begin{array}{c}\text { Valid } \\
\text { percent }\end{array}$ & $\begin{array}{c}\text { Cumulative } \\
\text { percent }\end{array}$ \\
\cline { 2 - 6 } & Disagree & 2 & 5.4 & 5.4 & 5.4 \\
\hline Neutral & 2 & 5.4 & 5.4 & 10.8 \\
\hline & Agree & 21 & 56.8 & 56.8 & 67.6 \\
\hline Strongly Agree & 12 & 32.4 & 32.4 & 100.0 \\
\hline & Total & 37 & 100.0 & 100.0 & \\
\hline
\end{tabular}

Table 4: The plant management based on to retain all data and information about customer by technological service (computerize system).

about customers, also $72.2 \%$ from employees have extremely strong agreed about their company which should keep all documents for customers. It leads to giving an extremely positive impact on the company and its customers as it shows in Table 4.

\section{Internet and marketing}

The plant management is not much adopted the use of the internet in the marketing processes of the product to reduce production costs and increase customer satisfaction. This indicates a lack of optimal using of technology. While, exist of technology, customer archive and a computerization system in the factory. Overall this variables positive impact on productivity. On the contrary, technology does not apply in the best way. This is evident from the responses of the respondents, where the percentage of use of technology in the factory for the Internet was about $48 \%$. This effect is not positive for management, taking into account that the presence of technology and its use in marketing and production processes through the internet which is clear in Table 5.

\section{Employees training}

In this section presents of the statistics analysis of workers training on use modern technology by developing a time schedule to improve production. It can be noted that the percent of research sample was $29.7 \%$ as demonstrate Table 6, who said wish the plant management does not base to work on employees training. On the other words, the workers do not get on perfectly skills in this factory in this discussion above. It might aim us to conclude that there appears a substantially large impact of training on productivity.

\section{Conclusion}

This is important to understanding that the technologies are basic in organizations. In terms of we can see the difference from the kinds of

\begin{tabular}{|c|c|c|c|c|c|}
\hline Valid & Frequency & Percent & $\begin{array}{c}\text { Valid } \\
\text { percent }\end{array}$ & $\begin{array}{c}\text { Cumulative } \\
\text { percent }\end{array}$ \\
\cline { 2 - 6 } & Strongly Disagree & 3 & 8.1 & 8.1 & 8.1 \\
\hline Disagree & 9 & 24.3 & 24.3 & 32.4 \\
\hline & Neutral & 7 & 18.9 & 18.9 & 51.4 \\
\hline Agree & 10 & 27.0 & 27.0 & 78.4 \\
\cline { 2 - 6 } & Strongly Agree & 8 & 21.6 & 21.6 & 100.0 \\
\hline & Total & 37 & 100.0 & 100.0 & \\
\hline
\end{tabular}

Table 5: The plant management adopted the use of the Internet in the marketing processes of the product to reduce production costs and increase customer satisfaction.

\begin{tabular}{|c|c|c|c|c|c|}
\hline Valid & Frequency & Percent & $\begin{array}{c}\text { Valid } \\
\text { percent }\end{array}$ & $\begin{array}{c}\text { Cumulative } \\
\text { percent }\end{array}$ \\
\cline { 2 - 6 } & Strongly Disagree & 11 & 29.7 & 29.7 & 29.7 \\
\hline Disagree & 9 & 24.3 & 24.3 & 54.1 \\
\hline Neutral & 6 & 16.2 & 16.2 & 70.3 \\
\hline Agree & 10 & 27.0 & 27.0 & 97.3 \\
\hline & Strongly Agree & 1 & 2.7 & 2.7 & 100.0 \\
\hline & Total & 37 & 100.0 & 100.0 & \\
\hline
\end{tabular}

Table 6: The plant management achieves to the training of employees to use modern technology by developing a time schedule to improve production.

technologies in cross the world. Even though technology users might the use of the technologies and understand the best way of circumstances to use it. This is not enough to reaching of increase productivity alone without other variables in the system. To seek how productivity can be improved with the use of technologies one has to apply a holistic view to unify all variables specifically. Such as communication, the internet, and training, we have illustrated that the bulk of the evidence from this study is that technology does have ability to improve and develop of individuals skills also, significant impact on productivity.

Overall, it can be the conclusion that the impact of technologies on workers' productivity is not limited in huge ways. In the worst case, employees have not too high skills in use technology due to they have lacked to good training. Additionally, when the employee is not good skills and lack of perfect training that is consider a big element and effect on productivity in the workplace. To increase productivity, the administration should have up-to-date internal communication guidelines and organize pieces of training and other support for employees, particularly when new technology. We have suggested that of organizing training for whole employees basic to develop them and then improve themselves and increase productivity.

\section{References}

1. Mark D, Timothy D, Kenneth T (1997) Workers, wages, and technology. Q J Econ 112: 253-290.

2. John V, Reenen RS (2005) information technology and productivity. It ain't what you do it's the way that you do I.T.

3. Konings $J$ Vanormelingen S (2010) The impact of training on productivity and wages: firm level evidence, IZA Discussion Papers, No. 4731.

4. Kristen P, Lee R. Pew Research Center (December 2014) Technology's Impact on Workers.

5. Kimmo $P$ (2012) The impact of communication technologies on individual workers' productivity. $\mathrm{k} 77303$.

6. Doroshev VG (1988) Physiological regulation at the workplace. Nauka Press, Leningrad.

7. Gavrilov EV, Dmitrichenko MF, Dolya VK (2008) Systemology in transport Ergonomics. Znannya Press, Kiev. 
Citation: Niri AAM (2017) The Impact of Technology Factors on the Workers' Productivity an Empirical Study on Al Borg Cement Factory in Libya. Int J Econ Manag Sci 6: 435. doi: 10.4172/2162-6359.1000435

Page 4 of 4

8. Rohan S, Madhumita M (2012) Impact of Training Practices on Employee Productivity: A Comparative Study 2: 87-92.

9. Colombo E, Stanca L (2008) The Impact of Training on Productivity: Evidence from a Large Panel of Firms 35: 1140-1150.
10. Sepulveda F (2005) Training and Productivity: Evidence for US Manufacturing Industries. Oxf Econ 62: 504-528.

11. Konings J, Vanormelingen S (2009) The Impact of training on productivity and wages: Firm Level Evidence, Discussion. Paper No. 244. 